\title{
Airway endothelin levels in asthma: influence of endobronchial allergen challenge and maintenance corticosteroid therapy
}

\author{
A.E. Redington*, D.R. Springall**, M.A. Ghatei ${ }^{+}$, J. Madden*, \\ S.R. Bloom ${ }^{+}$, A.J. Frew*, J.M. Polak**, S.T. Holgate* P.H. Howarth*
}

Airway endothelin levels in asthma: influence of endobronchial allergen challenge and maintenance corticosteroid therapy. A.E. Redington, D.R. Springall, M.A. Ghatei, J. Madden, S.R. Bloom, A.J. Frew, J.M. Polak, S.T. Holgate, P.H. Howarth. @ERS Journals Ltd 1997.

ABSTRACT: Endothelins (ETs) are 21 amino acid peptides which, in addition to their other properties, are potent bronchoconstrictors. Whilst there is evidence of the involvement of ET in the pathophysiology of chronic asthma, its contribution to the acute allergic response is undefined.

To examine this, we have undertaken segmental bronchoprovocation with allergen and saline at separate sites in six atopic asthmatics receiving treatment with bronchodilators only and six atopic asthmatics additionally receiving treatment with inhaled corticosteroids. Each challenged segment was lavaged $\mathbf{1 0}$ min after bronchoprovocation and concentrations of immunoreactive ET were measured in bronchoalveolar lavage fluid.

In the non-steroid-treated subjects, there were significantly lower ET levels at the allergen-challenged sites compared to the saline-challenged sites $(p<0.05)$. In the steroid-treated subjects, on the other hand, there was no significant difference between the two sites. Levels of ET at the saline-challenged sites were significantly lower in the steroid-treated subjects compared to the non-steroid-treated subjects $(\mathrm{p}<0.04)$.

These findings do not support the hypothesis that allergen exposure in asthma results in immediate release of endothelin. However, release at later time-points and a role for endothelin in late-phase bronchoconstriction are not excluded.

Eur Respir J 1997; 10: 1026-1032.
*University Medicine, Southampton General Hospital, UK. Depts of **Histochemistry and + Medicine, Royal Postgraduate Medical School, Hammersmith Hospital, London, UK.

Correspondence: A.E. Redington

Room 4H17-21

Health Sciences Centre

Dept of Pathology

McMaster University

1200 Main Street West

Hamilton

Ontario

Canada L8N $3 Z 5$

Keywords: Allergen challenge asthma

bronchoalveolar lavage

bronchoscopy

corticosteroids

endothelin

Received: June 171996

Accepted after revision January 261997

This work was supported by the Medical Research Council (UK).
The human endothelin (ET) family comprises three 21 amino acid peptides termed ET-1, ET-2 and ET-3 [1]. Endothelin-1 was originally characterized as a potent vasoconstrictor [2], but ETs are now recognized to have many other biological properties. Of particular relevance to asthma, all three isopeptides are potent contractile agonists of isolated human airways [3], while ET-1 causes bronchoconstriction in vivo in guinea-pigs when administered either intravenously [4] or by inhalation [5]. In addition, ET-1 has been shown to stimulate secretion of mucus in isolated tracheal preparations [6], to activate inflammatory cells including macrophages [7] and mast cells [8] in vitro, and to exert pulmonary proinflammatory effects in vivo in guinea-pigs [9]. Finally, ET-1 is mitogenic both for fibroblasts [10] and airway smooth muscle [11], suggesting a possible role in airway wall remodelling in asthma.

Members of the ET family exert their effects via an interaction with specific membrane receptors. In a variety of systems, two receptors have been characterized, which are denoted ETA and ETB [12]. The ETA receptor has a higher affinity for ET-1 or ET-2 as compared with ET-3, whereas the ETB receptor has equal affinity for the three members. Contraction of human bronchi is believed to be principally ETB-mediated [13], whereas other properties of ETs relevant to asthma, such as secretion of mucus and mitogenic responses, are likely to involve ETA receptors.

There are a number of potential sources of ET within the airway wall, including bronchial epithelial cells [14], vascular endothelial cells [2] and inflammatory cells, such as macrophages [15] and possibly also mast cells [16], although a mast cell origin has not yet been demonstrated in humans. In bronchial biopsies, a major site of immunoreactivity for ET is the airway epithelium [17, 18]. Expression at this site is increased in asthma [19] and, consistent with this, ET levels in bronchoalveolar lavage (BAL) fluid from non-corticosteroid-treated asthmatics are increased in comparison with those in BAL fluid from healthy control subjects [20, 21]. As these levels correlate with the degree of airflow obstruction in asthma [21], it has been proposed that ET contributes to the resting bronchomotor tone in this disease.

We hypothesized that ET may be released during acute allergen exposure and, thereby, contribute to the immdiate bronchoconstrictor response. To investigate the 
relationship between allergen exposure and ET release in vivo, we have used a segmental bronchoprovocation model. Twelve atopic asthmatic subjects, six of whom were receiving regular maintenance therapy with inhaled corticosteroids, underwent fibreoptic bronchoscopy with endobronchial allergen and sham saline challenges into separate bronchopulmonary segments. BAL was then performed in each segment during the immediate phase of bronchoconstriction, and concentrations of immunoreactive ET in BAL fluid were determined by radioimmunoassay.

\section{Materials and methods}

\section{Subjects}

Six atopic asthmatics (2 males and 4 females; aged $23 \pm 1 \mathrm{yr}$ ), treated only with inhaled short-acting $\beta_{2}$-agonists as required, and a further six atopic asthmatics (1 male and 5 females; aged $27 \pm 2$ yrs), additionally receiving regular therapy with inhaled corticosteroids, took part in the study. Their clinical and physiological parameters are summarized in table 1. One subject in the steroid-treated group was also receiving treatment with the long-acting $\beta_{2}$-agonist salmeterol. All subjects were nonsmokers, had mildly symptomatic clinically stable asthma, and none had experienced recent symptoms of upper respiratory tract infection. The study was approved by the Southampton Joint University and Hospitals Ethics Committee, and all subjects gave written informed consent.

\section{Physiological measurements}

Subjects attended, 1-2 weeks prior to bronchoscopy, for measurement of forced expiratory volume in one second (FEV1) and airway reactivity and determination of atopic status. On this occasion, those subjects receiving inhaled short-acting $\beta_{2}$-agonists had been asked to discontinue this medication for a minimum of $6 \mathrm{~h}$ beforehand.
The technique used to determine airway reactivity was adapted from the five breath procedure described by $\mathrm{CHAI}_{\mathrm{HA}}$ et al. [22]. All solutions were administered from an Inspiron nebulizer (CR Bard, Sunderland, UK) driven by compressed air at a flow rate of $8 \mathrm{~L} \cdot \mathrm{min}^{-1}$. After resting for $15 \mathrm{~min}$, the baseline FEV1 was recorded using a wedge bellows spirometer (Vitalograph Ltd, Buckingham, UK). Subjects then inhaled five breaths of $0.9 \%$ saline via a mouthpiece, each breath taken from functional residual capacity (FRC) to total lung capacity (TLC), and further measurements of FEV1 were made after 1 and 3 min. Subjects proceeded to inhale increasing doubling concentrations $\left(0.03-16 \mathrm{mg} \cdot \mathrm{mL}^{-1}\right.$ saline) of histamine (BDH, Lutterworth, Leicestershire, UK), with FEV1 measurements made at 1 and $3 \mathrm{~min}$ after each inhalation. These stepwise inhalations continued until either the FEV1 had fallen by at least $20 \%$ of the postsaline value or until the maximum concentration had been reached. The $\log _{10}$ concentration of agonist was plotted against the percentage change in FEV1 from the postsaline value, and the cumulative provocative concentration causing a $20 \%$ fall in FEV1 (PC20) was derived by linear interpolation between the last two data-points.

Atopic status was determined by skin-prick testing using the following allergen extracts: Dermatophagoides pteronyssinus, cat allergen, mixed feathers, mixed grass pollens and dog allergen (Miles Inc, Hollister Stier, Elkhart, IN, USA). A drop of each allergen solution was placed on the skin of the volar surface of the forearm and a small volume of solution introduced into the epidermis using sterile $1 \mathrm{~mm}$ lancets (Entaco Ltd, Studley, Warwickshire, UK). A positive response was defined as a wheal diameter $\geq 3 \mathrm{~mm}$ measured at $15 \mathrm{~min}$ to one or more allergen extract, in the presence of negative $(0.9 \%$ saline) and positive (histamine acid phosphate) controls. A skin-prick test wheal dose-response series was then performed using serial 10 fold dilutions of the allergen that produced the largest response, in order to determine the concentration to be used for segmental bronchoprovocation. The lowest concentration which produced a $\geq 3 \mathrm{~mm}$ diameter wheal response was chosen for the endobronchial challenge.

Table 1. - Clinical and physiological characteristics of the subjects studied

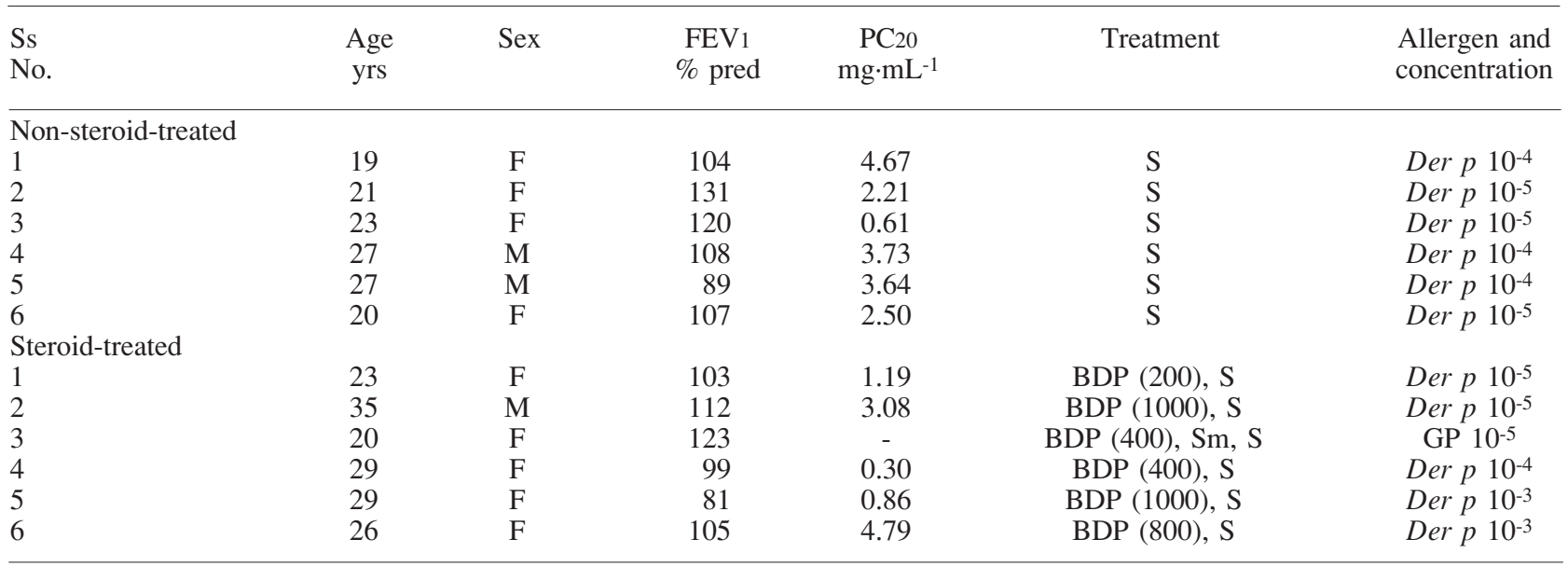

Ss: subjects; F: female; M: male; FEV1: forced expiratory volume in one second; PC20: provocative concentration of histamine producing a $20 \%$ fall in FEV1: BDP: beclomethasone dipropionate, with total daily dose in $\mu \mathrm{g}$ in parenthesis; Sm: salmeterol; S: salbutamol; Der p: Dermatophagoides pteronyssinus; GP: grass pollen. 
Fibreoptic bronchoscopy and endobronchial allergen challenge

Fibreoptic bronchoscopy, endobronchial allergen challenge and BAL were performed in accordance with our published procedure [23], conforming to current National Heart, Lung and Blood Institute (NHLBI) guidelines [24]. Premedication consisted of nebulized salbutamol 5 $\mathrm{mg}$ and ipratropium bromide $0.5 \mathrm{mg}$, intravenous atropine $0.6 \mathrm{mg}$, and intravenous midazolam as required (median 6.5 (range $0-8) \mathrm{mg}$ ). Lignocaine 10 and $4 \%$ spray was used to achieve anaesthesia of the upper airways, and a flexible Olympus BFIT20 fibreoptic bronchoscope (Olympus Optical Co., Tokyo, Japan) was inserted either via the nasal or oral route. Further aliquots of $1 \%$ lignocaine were applied to the larynx and lower airways. The tip of the bronchoscope was then wedged into the medial segment of the middle lobe and $20 \mathrm{~mL}$ of pyrogen-free $0.9 \%$ saline, prewarmed to $37^{\circ} \mathrm{C}$, were instilled. The instrument was withdrawn and was next wedged into the anterior segment of the right upper lobe, where 20 $\mathrm{mL}$ of the prewarmed allergen solution was similarly applied. Appearances were observed in order to confirm that airway narrowing occurred at the allergen-challenged segment. Ten minutes after challenge, BAL was performed at each site by instilling $6 \times 20 \mathrm{~mL}$ aliquots of $0.9 \%$ saline, with recovery by gentle aspiration after each application. From the total sample of BAL fluid recovered, $10 \mathrm{~mL}$ were withdrawn and immediately mixed with $0.2 \mathrm{~mL}$ aprotinin $(10,000$ kallikrein inactivator units $\cdot \mathrm{mL}^{-1}$ ) (Bayer Ltd, Newbury, Berkshire, UK) in order to minimize degradation of ET by BAL fluid proteases. Oxygen was administered at a rate of $2 \mathrm{~L} \cdot \mathrm{min}^{-1}$ throughout the procedure, and oxygen saturation was measured continuously by means of a digital pulse oximeter (Pulsox7; Minolta, Tokyo, Japan). Subjects were observed in the department for at least $3 \mathrm{~h}$ after completion of the procedure.

\section{BAL fluid total and differential cell counts}

After centrifugation, the cell pellet was resuspended in phosphate-buffered saline (PBS, pH 7.4) and total cell concentrations were determined using a Neubauer haemocytometer (BDH, Dagenham, Essex, UK). The cell concentration was adjusted to $5 \times 10^{5}$ cells $\cdot \mathrm{mL}^{-1}$ and cell preparations for differential counts were prepared by cytocentrifugation (Cytospin; Shandon Scientific Limited, Runcorn, Cheshire, UK) using $100 \mu \mathrm{L}$ aliquots of the cell suspension per slide. These preparations were air-dried, fixed in methanol, and stained using the Hema "Gurr" rapid staining set (BDH, Lutterworth, Leicestershire, UK). Differential cell counts were performed, counting 500 cells per slide.

\section{ET extraction and radioimmunoassay}

After thawing, BAL fluid specimens were acidified by addition of $2 \mathrm{~mL}$ of $4 \%$ (v/v) acetic acid, centrifuged, and ET was extracted using Sep-Pak $\mathrm{C}_{18}$ cartridges (Waters Associates, Milford, MA, USA). Sep-Pak cartridges were activated by preconditioning with $10 \mathrm{~mL}$ of $100 \%$ ace- tonitrile, $10 \mathrm{~mL}$ of $100 \%$ methanol and then $10 \mathrm{~mL}$ of $4 \%$ acetic acid. The samples were loaded and immunoreactive ET was eluted with $2 \mathrm{~mL}$ of $60 \%(\mathrm{v} / \mathrm{v})$ acetonitrile/water containing $0.03 \mathrm{M}$ ammonium acetate. The eluate was dried in a vacuum centrifuge (Savant Instruments Inc, Hicksville, NY, USA) and the resulting pellet was reconstituted with assay buffer $(60 \mathrm{mM}$ phosphate buffer, pH 7.4, containing $10 \mathrm{mM}$ ethylenediamine tetraacetic acid (EDTA), $7 \mathrm{mM}$ sodium azide, and $0.3 \%(\mathrm{w} / \mathrm{v})$ bovine serum albumin (BSA)). The recovery of peptide by this extraction procedure was estimated by adding synthetic ET- 1 to buffer $\left(0.2\right.$ and $\left.1 \mathrm{fmol} \cdot \mathrm{mL}^{-1}\right)$ yielding $64 \pm 4$ and $83 \pm 6 \%(n=4)$ recovery, respectively.

The ET radioimmunoassay has been described in detail previously [25], but the antibody used in the present study was obtained from a subsequent bleed of the immunized rabbit and gave increased sensitivity. This assay could detect changes of 0.05 fmol-tube- 1 at $95 \%$ confidence with duplicate tubes. The antibody shows 60, 70 and $0.1 \%$ cross-reactivity with ET-2, ET-3 and big ET-1, respectively, but no cross-reactivity with other pulmonary neuropeptides tested, including neuropeptide Y, substance $\mathrm{P}$, vasoactive intestinal peptide (VIP), bombesin and galanin.

\section{Statistical analyses}

Results for age, FEV1 \% predicted, and BAL fluid return volumes were expressed as mean \pm standard error of mean (SEM). Comparisons of these measurements were performed using paired and unpaired t-tests. Airway reactivity values were expressed as geometric mean (range) and BAL fluid ET concentrations and cell numbers as median (range), as these data were not normally distributed. Comparisons of these measurements were performed using the Wilcoxon test for paired data and the Mann-Whitney U-test for unpaired data, as appropriate. Correlations were sought using Spearman's test. A p-value of less than 0.05 was regarded as statistically significant. Statistical analysis was performed using StatView 4.02 for Macintosh (Abacus Concepts, Berkeley, CA, USA).

\section{Results}

There were no significant differences between the nonsteroid-treated and the steroid-treated subjects in age (23 \pm 1 vs $27 \pm 2$ yrs; $\mathrm{p}=0.14)$, FEV1 $(110 \pm 6$ vs $104 \pm 6 \%$ pred; $\mathrm{p}=0.48)$, or airway reactivity $(2.45(0.61-4.67) \mathrm{vs}$ $\left.1.35(0.30-4.79) \mathrm{mg} \cdot \mathrm{mL}^{-1} ; \mathrm{p}=0.47\right)$. Measurement of airway reactivity was not determined in one of the steroidtreated subjects (subject No. 3), who was additionally treated with the long-acting $\beta_{2}$-agonist salmeterol.

Bronchoscopy was generally well-tolerated, other than in one of the steroid-treated individuals (subject No. 4) with marked bronchial hyperresponsiveness, who developed bronchospasm during the procedure and required administration of nebulized salbutamol and intravenous hydrocortisone. Marked bronchoconstriction of the challenged segment was seen to occur in all subjects at the allergen-challenged site within a few minutes of exposure. In contrast, no bronchoconstriction was evident 
Table 2. - Total and differential cell counts in bronchoalveolar lavage (BAL) fluid

\begin{tabular}{|c|c|c|c|c|c|c|c|}
\hline & $\begin{array}{l}\text { Total cells } \\
\times 10^{5} \cdot \mathrm{mL}^{-1}\end{array}$ & $\begin{array}{c}\text { Macrophages } \\
\times 10^{5} \cdot \mathrm{mL}^{-1}\end{array}$ & $\begin{array}{l}\text { Lymphocytes } \\
\times 10^{5} \cdot \mathrm{mL}^{-1}\end{array}$ & $\begin{array}{l}\text { Neutrophils } \\
\times 10^{5} \cdot \mathrm{mL}^{-1}\end{array}$ & $\begin{array}{l}\text { Eosinophils } \\
\times 10^{5} \cdot \mathrm{mL}^{-1}\end{array}$ & $\begin{array}{l}\text { Basophils/ } \\
\text { mast cells } \\
\times 10^{5} \cdot \mathrm{mL}^{-1}\end{array}$ & $\begin{array}{l}\text { Epithelial } \\
\text { cells } \\
\times 10^{5} \cdot \mathrm{mL}^{-1}\end{array}$ \\
\hline \multicolumn{8}{|l|}{ Non-steroid-treated group } \\
\hline Saline-challenged site & $\begin{array}{c}83.5 \\
(74.0-401.0)\end{array}$ & $\begin{array}{c}71.0 \\
(66.6-319.8)\end{array}$ & $\begin{array}{c}3.26 \\
(1.04-52.2)\end{array}$ & $\begin{array}{c}3.40 \\
(1.63-38.0)\end{array}$ & $\begin{array}{c}0.74 \\
(0.15-12.9)\end{array}$ & $\begin{array}{c}0 \\
(0-0)\end{array}$ & $\begin{array}{c}0.15 \\
(0-4.02)\end{array}$ \\
\hline Allergen-challenged site & $\begin{array}{c}54.0 \\
(18.0-144.0)\end{array}$ & $\begin{array}{c}43.8 \\
(15.0-57.8)\end{array}$ & $\begin{array}{c}6.37 \\
(2.34-12.5)\end{array}$ & $\begin{array}{c}1.99 \\
(0.61-3.43)\end{array}$ & $\begin{array}{c}0.59 \\
(0.07-1.23)\end{array}$ & $\begin{array}{c}0 \\
(0-0)\end{array}$ & $\begin{array}{c}0 \\
(0-1.09)\end{array}$ \\
\hline \multicolumn{8}{|l|}{ Steroid-treated group } \\
\hline Saline-challenged site & $\begin{array}{c}57.5 \\
(7.0-131.0)\end{array}$ & $\begin{array}{c}46.3 \\
(6.08-109.4)\end{array}$ & $\begin{array}{c}7.19 \\
(0.70-8.50)\end{array}$ & $\begin{array}{c}1.57 \\
(0.14-2.16)\end{array}$ & $\begin{array}{c}0.63 \\
(0.06-0.72)\end{array}$ & $\begin{array}{l}0.09 \\
(0-0.48)\end{array}$ & $\begin{array}{c}0.24 \\
(0-1.73)\end{array}$ \\
\hline Allergen-challenged site & $\begin{array}{c}42.0 \\
(29.0-80.0)\end{array}$ & $\begin{array}{c}34.7 \\
(28.4-42.6)\end{array}$ & $\begin{array}{c}4.31 \\
(2.69-31.5)\end{array}$ & $\begin{array}{c}1.61 \\
(0.64-3.35)\end{array}$ & $\begin{array}{c}0.25 \\
(0.06-2.55)\end{array}$ & $\begin{array}{c}0 \\
(0-0.08)\end{array}$ & $\begin{array}{c}0.19 \\
(0-1.01)\end{array}$ \\
\hline
\end{tabular}

Cytocentrifuge preparations were unavailable or unsuitable for analysis in the case of one subject in the non-steroid-treated and two subjects in the steroid-treated group. Data are expressed as median, and range in parenthesis. Paired and unpaired comparisons were performed using the Wilcoxon and Mann-Whitney U-tests, respectively.

at the saline-challenged sites. There was no significant difference in BAL fluid return volumes between the saline- and allergen-challenged sites $(56.3 \pm 5.5$ vs $62.5 \pm 6.3$ $\mathrm{mL} ; \mathrm{p}=0.33$ ).

Total and differential cell counts in BAL fluid from both sites are presented in table 2. Considering data for the saline-challenged site, which may be regarded as reflecting basal values, there was a trend towards a reduction in total cell numbers $(\mathrm{p}=0.11)$ in the steroid-treated asthmatics compared to the non-steroid-treated asthmatics, but no significant differences in the numbers of individual cell types. There were no significant differences in either total or individual cell numbers between allergen- and saline-challenged sites in either group.

Immunoreactive ET was detectable in all BAL fluid samples. In the non-steroid-treated subjects, there were significantly lower ET concentrations at the allergen-challenged sites compared to the saline-challenged sites $(0.49$ (0.25-0.77) vs $0.78(0.23-1.53) \mathrm{pM} ; \mathrm{p}=0.046)$ (fig. 1). In the steroid-treated subjects, on the other hand, ET

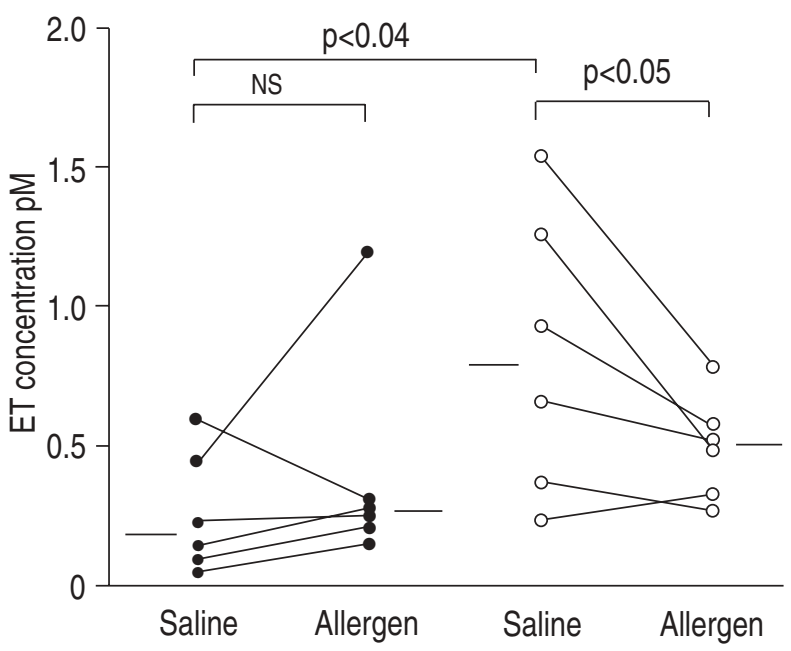

Fig. 1. - Concentrations of endothelin in bronchoalveolar lavage (BAL) fluid from allergen- and saline-challenged segments in steroidtreated $(\bullet)$ and non-steroid-treated $(O)$ subjects. Horizontal bars represent median values. ET: endothelin; NS: nonsignificant. concentrations tended to be slightly higher at the allergen-challenged sites, but this difference was not statistically significant $(0.26(0.15-1.18)$ vs $0.19(0.05-0.60)$ $\mathrm{pM} ; \mathrm{p}=0.25)$. The difference in ET concentration between the two challenged segments was significantly different between the non-steroid-treated and the steroid-treated groups, either when expressed as an absolute value $(-0.26$ vs $+0.10 \mathrm{pM} ; \mathrm{p}=0.025)$ or as a percentage $(-34.9$ vs $+95.8 \%$; $\mathrm{p}=0.037$ ). Concentrations of ET at the salinechallenged sites were significantly higher in the nonsteroid-treated subjects than the steroid-treated subjects (0.78 (0.23-1.53) vs 0.19 (0.05-0.60) pM; p=0.037). There were no significant correlations between ET measurements, total and differential cell counts, and physiological indices, either when considering the two groups separately or together.

\section{Discussion}

Segmental bronchoprovocation provides a valuable technique to study the cellular and biochemical events occurring within the airways of sensitized asthmatics in response to allergen exposure [26]. Using this method, previous investigators have provided evidence for the release of a number of spasmogenic mediators, including histamine, prostaglandins and leukotrienes, in association with immediate allergen-induced bronchoconstriction (reviewed in [27]). Endothelin is an extremely potent bronchoconstrictor, which has been linked to airflow obstruction in chronic stable asthma on the basis of increased expression in bronchial biopsies [19] and BAL fluid [20, 21]. In the present study, a segmental bronchoprovocation model was used to investigate whether ET release occurs in the airways following acute allergen exposure in asthma and whether this peptide might, thus, be implicated in immediate allergen-induced bronchoconstriction.

In asthmatics not receiving regular anti-inflammatory therapy with inhaled corticosteroids, concentrations of immunoreactive ET were found to be significantly lower at allergen-challenged sites in comparison with salinechallenged sites. This result was unexpected and failed to support our hypothesis that allergen exposure might 
induce ET release in the airways at this time-point. A possible explanation may be that one or more factors are released during the immediate allergic response which either rapidly metabolize or bind ET, thereby reducing its detection by radioimmunoassay and limiting its bronchoconstrictor potential. At present, there is little information regarding proteases responsible for degrading ET in vivo. It has been suggested that neutral endopeptidase (NEP) plays a role, as this enzyme is capable of degrading all three ET isopeptides in vitro [28]. In addition, it has been reported that activated leucocytes release enzymes which can degrade ET and which are distinct from NEP [29], although these have not yet been characterized in detail. Although our protocol involves the immediate addition of the protease inhibitor, aprotinin, it is possible that a high local concentration of BAL fluid proteases could overcome its protective effect or alternatively that metabolism may occur rapidly in vivo.

The demonstration of reduced BAL fluid ET levels following allergen exposure is consistent with other studies of ET in asthma. KRAFT et al. [30] reported a night-time decrease in BAL fluid ET levels in asthmatics with nocturnal asthma who were not treated with corticosteroids. Metabolism by proteases released from inflammatory cells or increased binding were proposed as possible explanations. In addition we have recently reported preliminary evidence that endobronchial hyperosmolar saline challenge in subjects with exercise-induced asthma results in reduced BAL fluid ET levels [31].

In contrast, in subjects who had been receiving regular treatment with inhaled corticosteroids, we were unable to demonstrate a significant difference in ET concentrations between allergen-challenged and saline-challenged sites. The efficacy of corticosteroids in asthma is considered to result from their ability to exert multiple anti-inflammatory effects in the airways, and a number of investigators have reported reductions in inflammatory cell numbers in bronchial biopsies following corticosteroid treatment $[32,33]$. The failure to demonstrate a difference in ET levels in the corticosteroid-treated subjects in the present study may, therefore, have resulted from a reduction in the degree of airways inflammation in response to corticosteroid therapy, with a consequent reduction in the release of ET degrading enzymes. This is supported by the finding of a trend towards a reduction in total cell numbers in the steroid-treated subjects, although we were not able to demonstrate significant reductions in the numbers of individual leucocytes, perhaps due to the wide range of measurements and the small numbers involved. In addition to absolute changes in cell numbers, it is possible that the ability of individual cells to release ET-degrading enzymes may also be reduced by corticosteroids.

Measurement of mediators in BAL fluid provides no direct information concerning the cellular origin of these mediators. In the case of ET, airway epithelial cells are likely to represent one important source, as a major site of ET expression in bronchial tissue, as determined both by immunohistochemistry $[17,18]$ and by in situ hybridization [17], is the airway epithelium. Human bronchial epithelial cells in vitro release ET into the culture medium, and the quantities released are increased in cells derived from asthmatic subjects [34]. However, although bronchial epithelial cells from a proportion of asthmatics express the low affinity immunoglobulin E (IgE) Fc epsilon receptor type II (FceRII) (CD23) and release ET in vitro via an IgE-dependent mechanism [35], release has not yet been demonstrated at a time-point as early as 10 min after stimulation. Inflammatory cells, particularly macrophages, must also be considered as likely contributors to ET in BAL fluid, as highlighted by a recent report demonstrating increased expression of immunoreactive ET by alveolar macrophages derived from asthmatic subjects [15]. In the present study, however, we were unable to demonstrate significant correlations between ET levels and numbers of macrophages or other leucocytes.

A further point of interest in the present study was the finding that concentrations of immunoreactive ET at the saline-challenged sites, which may be considered to reflect basal levels, were significantly lower in the steroid-treated subjects compared to the non-steroid-treated subjects. This may reflect reduced release from airway epithelial cells, as synthesis and release of ET by the pulmonary epithelial cell line A549 [36] and by cultured human bronchial epithelial cells [34] have been reported to be decreased by corticosteroids. Release of ET by macrophages might also be reduced by corticosteroids, although, to our knowledge, this has not yet been reported. In agreement with our present findings, previous investigators have reported a reduction in BAL fluid ET levels in vivo in asthma following a short course of oral prednisolone [20]. In our previous study [21], on the other hand, we were unable to demonstrate a significant difference between basal BAL fluid ET levels between non-steroidtreated and steroid-treated asthmatic subjects. The most likely explanation for this apparent discrepancy is that, whereas the steroid-treated group in the present study contained only subjects whose asthma was clinically wellcontrolled, in the earlier study this group also included several patients with more severe disease, who did not have fully suppressed airways inflammation as assessed by other parameters [21].

The antiserum used in the present study was raised against ET-1 but exhibits significant cross-reactivity both with ET-2 and ET-3. Evidence from fast protein liquid chromatography suggests that ET-1 and ET-3 are present in approximately equal amounts in BAL fluid, but that ET-2 cannot be detected [20]. This is in agreement with immunohistochemical studies indicating that preproET-1 and preproET-3, but not preproET-2, are expressed by bronchial epithelial cells [18]. The ET that we have been able to detect, therefore, is likely to reflect a combination of ET-1 and ET-3. Both these peptides can be considered relevant to the pathophysiology of asthma via their ability to interact with ETA (ET-1) and ETB (ET-1 and ET-3) receptors, both of which are present in human asthmatic airways [37].

Possible confounding factors in the present study include the use of the $\beta_{2}$-agonist salbutamol and the local anaesthetic lignocaine during the bronchoscopy. These agents are routinely administered in order to ensure the safety and tolerability of the procedure for our asthmatic volunteers. Although salbutamol is capable of abolishing the early bronchoconstrictor response seen in asthma following allergen inhalation challenge [38], we observed constriction of the allergen-challenged segment in each subject, indicating that any inhibitory effect of salbutamol 
was overcome by the high local concentration of allergen which is achieved with endobronchial instillation. The pharmacological effects of salbutamol and lignocaine on ET release from cultured cells have not been reported, however, and so there remains a theoretical possibility that these agents may have influenced our results. Finally, the subjects in the present study were predominantly female, although inspection of the individual datapoints did not suggest any noticeable effect of gender on ET levels.

In summary, the present results do not support the hypothesis that allergen exposure results in the release of endothelin in the airways sufficiently early to contribute to immediate bronchoconstriction. However, release at later time-points has not been excluded, and a role for endothelin in the late-phase bronchoconstrictor response remains possible. Our findings also highlight the fact that measurements of endothelin levels at any individual timepoint represent a net reflection of release and metabolism. Further studies are warranted on factors influencing both these processes.

Acknowledgements: The authors thank H. Brewster, J. Schreiber and S. Smith for technical assistance.

\section{References}

1. Inoue A, Yanagisawa M, Kimura S, et al. The human endothelin family: three structurally and pharmacologically distinct isopeptides predicted by three separate genes. Proc Natl Acad Sci USA 1989; 86: 2863-2867.

2. Yanagisawa M, Kurihara $\mathrm{H}$, Kimura $\mathrm{S}$, et al. A novel potent vasoconstrictor peptide produced by vascular endothelial cells. Nature 1988; 332: 411-415.

3. Advenier C, Sarria B, Naline E, Puybasset L, Lagente V. Contractile activity of three endothelins (ET-1, ET-2 and ET-3) on the human isolated bronchus. $\mathrm{Br} J$ Pharmacol 1990; 100: 168-172.

4. Payne AN, Whittle BJR. Potent cyclo-oxygenase-mediated bronchoconstrictor effects of endothelin in the guinea-pig in vivo. Eur J Pharmacol 1990; 158: 303-304.

5. Lagente V, Chabrier PE, Mencia-Huerta J-M, Braquet P. Pharmacological modulation of the bronchopulmonary action of the vasoactive peptide, endothelin, administered by aerosol in the guinea-pig. Biochem Biophys Res Commun 1989; 158: 625-632.

6. Shimura S, Ishihara H, Satoh M, et al. Endothelin regulation of mucus glycoprotein secretion from feline tracheal submucosal glands. Am J Physiol 1992; 262: L208L213.

7. Haller H, Schaberg T, Lindschau C, Lode H, Distler A Endothelin increases $\left[\mathrm{Ca}^{2+}\right]$ i, protein phosphorylation, and $\mathrm{O}_{2} .^{-}$production in human alveolar macrophages. $\mathrm{Am} \mathrm{J}$ Physiol 1991; 261: L478-484.

8. Uchida Y, Ninomiya H, Sakamoto T, et al. ET-1 released histamine from guinea-pig pulmonary but not peritoneal mast cells. Biochem Biophys Res Commun 1992; 189: 1196-1201.

9. Filep JG, Fournier A, Földes-Filep E. Acute proinflammatory actions of endothelin-1 in the guinea-pig lung: involvement of ETA and ETB receptors. Br J Pharmacol 1995; 115: 227-236.

10. Takuwa N, Takuwa Y, Yanagisawa M, Yamashita K,
Masaki T. A novel vasoactive peptide endothelin stimulates mitogenesis through inositol lipid turnover in Swiss 3T3 fibroblasts. J Biol Chem 1989; 264: 7856-7861.

11. Glassberg MK, Ergul A, Wanner A, Puett D. Endothelin1 promotes mitogenesis in airway smooth muscle cells. Am J Respir Cell Mol Biol 1994; 10: 316-321.

12. Sakurai T, Yanagisawa M, Masaki T. Molecular characterization of endothelin receptors. TIPS 1992; 13: 103-108.

13. Adner M, Cardell LO, Sjöberg T, Ottosson A, Edvinsson L. Contractile endothelin-B (ЕTB) receptors in human small bronchi. Eur Respir J 1996; 9: 351-355.

14. Mattoli S, Mezzetti M, Riva G, Allegra L, Fasoli A. Specific binding of endothelin on human bronchial smooth muscle cells in culture and secretion of endothelin-like material from bronchial epithelial cells. Am J Respir Cell Mol Biol 1990; 3: 145-151.

15. Chanez P, Vignola AM, Albat B, et al. Involvement of endothelin in mononuclear phagocyte inflammation in asthma. J Allergy Clin Immunol 1996; 98: 412-420.

16. Ehrenreich H, Burd PK, Rottem M, et al. Endothelins belong to the assortment of mast cell-derived and mast cell-bound cytokines. New Biol 1991; 4: 147-156.

17. Giaid A, Polak JM, Gaitonde V, et al. Distribution of endothelin-like immunoreactivity and mRNA in the developing and adult human lung. Am J Respir Cell Mol Biol 1991; 4: 50-58.

18. Marciniak SJ, Plumpton C, Barker PJ, Huskisson NS, Davenport AP. Localization of immunoreactive endothelin and proendothelin in the human lung. Pulm Pharmacol 1992; 5: 175-182.

19. Springall DR, Howarth PH, Counihan H, Djukanovic R, Holgate ST, Polak JM. Endothelin immunoreactivity of airway epithelium in asthmatic patients. Lancet 1991; 337: 697-701.

20. Mattoli S, Soloperto M, Marini M, and Fasoli A. Levels of endothelin in the bronchoalveolar fluid of patients with symptomatic asthma and reversible airflow obstruction. J Allergy Clin Immunol 1991; 88: 376-384.

21. Redington AE, Springall DR, Ghatei MA, et al. Endothelin in bronchoalveolar lavage fluid and its relation to airflow obstruction in asthma. Am J Respir Crit Care Med 1995; 151: 1034-1039.

22. Chai H, Farr RS, Froehlich LA, et al. Standardization of bronchial inhalation challenge procedures. J Allergy Clin Immunol 1975; 56: 323-327.

23. Krug N, Teran LM, Redington AE, et al. Safety aspects of local endobronchial allergen challenge in asthmatic patients. Am J Respir Crit Care Med 1996; 153: 13911397.

24. National Heart, Lung, and Blood Institute workshop summary Investigative use of bronchoscopy, lavage and bronchial biopsies in asthma and other airways diseases. Eur Respir J 1992; 5: 115-121.

25. Takahashi K, Brooks RA, Kanse SM, Ghatei MA, Kohner EM, Bloom SR. Production of endothelin-1 by cultured bovine retinal endothelial cells and presence of endothelin receptors on associated pericytes. Diabetes 1989; 38: 1200-1202.

26. Makker HK, Montefort S, Holgate S. Investigative use of fibreoptic bronchoscopy for local airway challenge in asthma. Eur Respir J 1993; 6: 1402-1408.

27. Redington AE, Polosa R, Walls AF, Howarth PH, Holgate ST. Role of mast cells and basophils in asthma. Chem Immunol 1995; 62: 22-59.

28. Vijayaraghavan J, Scicli AG, Carretero OA, Slaughter C, Moomaw C, Hersh LB. The hydrolysis of endothelins by 
neutral endopeptidase 24.11 (enkephalinase). J Biol Chem 1990; 265: 14150-14155.

29. Sessa WC, Kaw S, Hecker M, Vane JR. The biosynthesis of endothelin-1 by human polymorphonuclear leukocytes. Biochem Biophys Res Commun 1991; 174: 613-618.

30. Kraft M, Beam WR, Wenzel SE, Zamora MR, O'Brien RF, Martin RJ. Blood and bronchoalveolar lavage endothelin-1 levels in nocturnal asthma. Am J Respir Crit Care Med 1994; 149: 947-952.

31. Makker HK, Ghatei M, Bloom SR, et al. Bronchoconstriction following local endobronchial challenge with hypertonic saline is associated with reduced endothelin levels in lavage. (Abstract) Eur Respir J 1994; 7: 51s.

32. Djukanovic R, Wilson JW, Britten KM, et al. Effect of an inhaled corticosteroid on airway inflammation and symptoms in asthma. Am Rev Respir Dis 1992; 145: 669-674.

33. Jeffery PK, Godfrey RW, Ädelroth E, Nelson F, Rogers A, Johansson S-A. Effects of treatment on airway inflammation and thickening of basement membrane reticular collagen in asthma: a quantitative light and electron microscopic study. Am Rev Respir Dis 1992; 145: 890-899.
34. Vittori E, Marini M, Fasoli A, de Franchis R, Mattoli S. Increased expression of endothelin in bronchial epithelial cells of asthmatic patients and effect of corticosteroids. Am Rev Respir Dis 1992; 146: 1320-1325.

35. Campbell AM, Vignola AM, Chanez P, Godard P, Bousquet J. Low-affinity receptor for $\mathrm{IgE}$ on human bronchial epithelial cells. Immunol 1994; 82: 506-508.

36. Calderón E, Gómez-Sánchez CE, Cozza EN, et al. Modulation of endothelin-1 production by a pulmonary epithelial cell line. I. Regulation by glucocorticoids. Biochem Pharmacol 1994; 48: 2065-2071.

37. Goldie RG, Henry PJ, Knott PG, Self GJ, Luttmann MA, Hay DWP. Endothelin-1 receptor density, distribution, and function in human isolated asthmatic airways. Am J Respir Crit Care Med 1995; 152: 1653-1658.

38. Cockcroft DW, Murdock KY. Comparative effects of inhaled salbutamol, sodium cromoglycate, and beclomethasone dipropionate on allergen-induced early asthmatic responses, late asthmatic responses, and increased bronchial responsiveness to histamine. J Allergy Clin Immunol 1987; 79: 734-740. 